\title{
Instructors and Students Relations: Argumentativeness, Leadership and Goal Orientations
}

\author{
Alexandra Bekiari, Katerina Balla \\ Faculty of Physical Education and Sports Science, University of Thessaly, Thessaly, Greece \\ Email: sandrab@pe.uth.gr
}

How to cite this paper: Bekiari, A. and Balla, K. (2017) Instructors and Students Relations: Argumentativeness, Leadership and Goal Orientations. Open Journal of Social Sciences, 5, 128-143.

https://doi.org/10.4236/jss.2017.57009

Received: June 10, 2017

Accepted: July 10, 2017

Published: July 13, 2017

Copyright ( $\odot 2017$ by authors and Scientific Research Publishing Inc. This work is licensed under the Creative Commons Attribution International License (CC BY 4.0).

http://creativecommons.org/licenses/by/4.0/ (c) (i) Open Access

\begin{abstract}
Focusing on argumentativeness, leadership and personal orientations, this study aims at: a) investigating the differences concerning gender and class, $b$ ) examining the relation between perceived instructors' argumentativeness, teaching leadership style and students' goal orientations, c) investigating the influence of instructors' argumentativeness on their leadership style and students' goal orientations in physical education context and d) proposing a students' and instructors' typology. The sample consisted of 260 students (127 males, 133 females) aged $10-12$ years old $(M=11.2, S D=0.67)$ from primary public schools who completed three types of questionnaires during physical education classes. The results supported the internal consistency of the instruments. According to the results of the study, statistically significant differences were observed in students' ego orientation between the genders and the classes of the students. Correlational analysis indicated that perceived instructors' argumentativeness was positively related to democratic teaching leadership style, students' task orientations and was negatively related to autocratic teaching leadership style, students' ego orientations. The results of regression analysis revealed that perceived instructors' argumentativeness could significantly predict the variables of teaching leadership style and students' goal orientations. Four behavioral types are revealed: 1) "learning by democracy and arguing", 2) "just democracy and arguing", 3) "just ego without learning" and 4) "learning by arguing".
\end{abstract}

\section{Keywords}

Argumentativeness, Leadership Style, Personal Orientations, Typology, Physical Education 


\section{Introduction}

\subsection{Argumentativeness}

It has been supported that the way of instructors' communication in classroom noticeably determines the learning process [1]-[19]. Argumentativeness is an important parameter of modern time [20] [21] [22]. Specifically, it is conceptualized as the predisposition to defend one's position on controversial issues while attempting to refute another person's position [23] [24]. Argumentativeness has been investigated in various fields [25], such as school class [26] [27] [28] [29], workplace [30] [31] [32], family [33] [34] as well as among adolescents [35]. Argumentativeness is positively correlated with learning outcomes like affection, motivation, intrinsic discipline reasons and students' satisfaction [36][42]. The use of arguments facilitates the learning process and encourages cooperative action [43]. Moreover, teachers' argumentativeness is positively correlated with physical, social and scientific attraction [44]. Furthermore, it positively influences students' motives [39], as the class is satisfied and emotional learning is favored [41]. Due to argumentativeness, communication becomes reliable and more powerful [45] [46] [47]. Apart from that, it was found that effective use of arguments results in the positive perception of leadership [45] [48].

\subsection{Leadership Style}

The Multidimensional Model of Leadership includes five leadership styles: democratic, autocratic, training and instruction, social support and positive feedback. The democratic teacher allows students' participation in decision making, whereas the autocratic teacher imposes his opinion [49]. It was found that students feel greater satisfaction when teacher adopts a supportive leadership style [50]. Moreover, group members are more satisfied with the democratic leader than the autocratic one [51] [52]. Socially supportive leaders provide stronger motives, increase students' satisfaction as well as their desire to participate in a physical activity [53]. Leader's behavior is also crucial for group's cohesion [54]. Training, instruction and positive feedback are considered the most preferable leadership styles, whereas autocratic leadership is undesirable [55]. Nevertheless, students mention that they are satisfied with democratic style and social supportiveness [56]. The socially supportive leadership style enhances morale and collective efficiency [57], students' satisfaction [50], motivation and their desire to participate in a physical activity [53]. Teachers' positive feedback strengthens self-efficacy [58]. Moreover, teachers' encouragement is crucial for the outcome [59]. Training and instruction style is negatively correlated with anxiety [60], whereas autocratic style is positively correlated with anxiety, as well as with the use of verbally aggressive communication [61].

\subsection{Goal Orientations}

Achievement goal theory was initially developed from [62] [63] and investigates 
motives in relation to each person's goal achievement, depending on his activity field, where children perceive their ability in two different ways: ego-orientation (people evaluate their ability in relation to other people) and task-orientation (people evaluate their ability according to their personal improvement). There are people that are oriented in both goals or in none of them [64]. Specifically, it was found that high level athletes are oriented in ego and task at the same time, possibly because high competition is a strong motive to overcome the competitors [65] [66]. People that are ego-oriented, try in every way to prove that they are better than the others, aiming at exhibiting their abilities. They think that it is a success to overcome the others. On the other side, people who are taskoriented, think that it is a success to be personally improved [66]. [67] [68] found that people, who are task-oriented, believe that slow progress and not meeting their expectations are a good opportunity to improve them, whereas people that are ego-oriented believe that these deficits constitute evidence of their low adequacy in relation to others. A motivation climate that promotes personal improvement and not competition creates the appropriate background for students' higher self-regulation and use of meta-cognitive strategies [69]. It was also found that the factor of social interaction influences achievement goals and interpersonal interactions [70].

\subsection{Innovation and Questions of the Study}

According to the arguments presented above, it is expected that issues of argumentativeness, leadership and orientations have been insightfully examined. However, the relations of students' goal orientations with argumentativeness and leadership style of instructors, as perceived by students, have not yet been explored.Here, relations among perceived argumentativeness and leadership style of instructors and students' goal orientationsat school are examined. The academic value of this research lies in the try to understand the relation between the afore-mentioned notions. The practical value is expected to consist in the empirical detection of settings and determinants of making the communication and the learning practice and behavior of instructors more effective. This practical value is supposed to further enhanced through more accurate observation made by the instructors in school, as they are going to be enabled to distinguish particular cases which are considered to need special handling.

Particularly, the following questions will be discussed:

- Are there any differences noted between the genders and class regarding argumentativeness, leadership style and goal orientations?

- Is there a positive or negative relationship between instructors' argumentativeness as perceived by students with teaching leadership style and students' self-reports of goal orientations in physical education classes?

- To what extent the perceived instructors' argumentativeness could be a significant predictor of their leadership style and the students' goal orientations?

- Can students' and instructors' typology regarding parameters of argumentativeness, leadership style perception and goal orientations be extracted? 


\section{Method}

\subsection{Participants and Procedures}

The sample of the study consisted of 260 students (127 males, 133 females) aged 10 - 12 years old $(M=11.2, S D=0.67)$ from primary public schools, Greece. All participants were at the $5^{\text {th }}$ grade (141 students) and $6^{\text {th }}$ grade (119 students) of public primary schools, originating from different socio-economic status. All students completed standardized questionnaires referring to the instructors' argumentativeness and leadership style and students' goal orientations, during their physical education lessons. The duration of completion was $20-30 \mathrm{mi}$ nutes and voluntary. The informants answered anonymously and voluntarily. Thus, the answers are supposed to be sincere. Research ethics as well as best practice rules were observed.

\subsection{Instruments}

Argumentativeness. The Greek version [44] was used to assess instructors' argumentativeness, based on the conceptualization of [39]. Preliminary examination [44] supported the psychometric properties of the instrument. In particular, confirmatory factor analysis indicated satisfactory fit indices (CFI: 0.98, SRMR: $0.05)$, and internal consistency of the scale $(\alpha=0.87)$. The scale consisted of ten items (e.g., "the teacher enjoys a good discussion with arguments on a controversial subject with his students", "the teacher avoids making use of arguments when he disagrees with his students"). Participants were asked to respond to the items based on a 5-point Likert-type scale ranging from $1=$ never to $5=$ always.

Leadership style. A shorter version of the Leadership Scale for Sports [49], adapted in Greek population [1] [61], was used in order to measure perceived instructors' leadership style. This short version consisted of 6 items describing autocratic leadership (e.g., "The instructor decides alone what to do regarding the organization and operation of the school") and 5 items describing democratic leadership teaching style (e.g., "The instructor allows students to set their own goals") only two of the five dimensions were used. Responses were given on a 5-point Likert-type scale ranging from 1: Strongly disagree to 5: Strongly agree.

Personal orientations. The Task and Ego Orientation questionnaire [64], adapted in Greek population [71] [72], was used to assess students' task and ego orientation. The scale consisted of two factors ("task" and "ego" orientation) and includes a total of 13 questions. Specifically, it is consisted of 7 questions describing task orientation (e.g., "learn a new exercise trying hard") and 6 questions describing the ego orientation (e.g., "am the only one who can do the exercise"). Participants were asked to respond on a 5 point Likert scale (from $1=$ never to $5=$ often).

\subsection{Data Analysis}

Data analysis included the use of the Statistical Package for Social Sciences (SPSS 21.0). The t-test for independent samples was used in order to reveal statistical 
significant differences between genders and classes of the students. The Pearson correlation coefficient was used to measure the correlation between the subscales of the questionnaires.Regression analysis was conducted in order to explore the extent to which the perceived instructors' argumentativeness could be a significant predictor of their leadership style and students' goal orientations. The level of statistical significance was set at .05. Finally, students' and instructors' typology regarding parameters of argumentativeness, leadership style and goal orientations will be formulated using principal component analysis.

\section{Results}

Statistically significant differences were observed in students' ego orientation $\left(\mathrm{t}_{1,258}=-2.11, \mathrm{p}<0.05\right)$ between the two genders of the students("Table 1"), while there were no differences between gender in argumentativeness $\left(t_{1,258}=\right.$ $0.19, \mathrm{p}=0.85)$, democratic style $\left(\mathrm{t}_{1,258}=0.45, \mathrm{p}=0.66\right)$, autocratic style $\left(\mathrm{t}_{1,258}=\right.$ $-0.11, \mathrm{p}=0.92)$ and task orientation $\left(\mathrm{t}_{1,258}=1.85, \mathrm{p}=0.07\right)$.

Additionally, sstatistically significant differences were observed in students' ego orientation $\left(t_{1,258}=-1.99, p<0.05\right)$ between the two classes of the students ("Table 1"). Specifically, the $5^{\text {th }}$ grade of primary school proved to have the higher score on ego orientation in comparison to $6^{\text {th }}$ grade. There were no statistically significant differences between classes in argumentativeness $\left(t_{1,258}=0.42\right.$, $\mathrm{p}=0.67)$, democratic style $\left(\mathrm{t}_{1,258}=1.33, \mathrm{p}=0.18\right)$, autocratic style $\left(\mathrm{t}_{1,258}=-1.36, \mathrm{p}\right.$ $=0.17)$ and task orientation $\left(\mathrm{t}_{1,258}=0.59, \mathrm{p}=0.56\right)$.

A correlation analysis was conducted, the results of which are presented in "Table 2". As it can be seen, there was a negative significant relationship between instructors' argumentativeness with autocratic style $(r=-0.49)$ and ego

Table 1. Students' gender and class comparison.

\begin{tabular}{cccccccc}
\hline & Gender & $\mathrm{N}$ & Mean & $\mathrm{SD}$ & $\mathrm{t}$ & $\mathrm{df}$ & $\mathrm{p}$ \\
\hline \multirow{2}{*}{ Ego orientation } & males & 127 & 3.27 & 0.79 & -2.11 & 258 & 0.036 \\
& females & 133 & 3.47 & 0.71 & & & \\
& Class & $\mathrm{N}$ & Mean & $\mathrm{SD}$ & $\mathrm{t}$ & $\mathrm{df}$ & $\mathrm{p}$ \\
& & & & & & & \\
Ego orientation & $5^{\text {th }}$ grade & 141 & 3.46 & 0.72 & -1.99 & 258 & 0.048 \\
& $6^{\text {th }}$ grade & 119 & 3.27 & 0.78 & & & \\
\hline
\end{tabular}

Table 2. Reliabilities, Means, Standard Deviations and Pearson Correlations among variables.

\begin{tabular}{|c|c|c|c|c|c|c|c|}
\hline & $\alpha$ & $\mathrm{M}(S D)$ & 1 & 2 & 3 & 4 & 5 \\
\hline 1. Argumentativeness & 0.68 & $3.00(0.72)$ & - & & & & \\
\hline 2. Autocratic style & 0.59 & $2.81(0.80)$ & $-0.49^{* *}$ & - & & & \\
\hline 3. Democratic style & 0.61 & $3.31(0.71)$ & $0.60^{\star *}$ & $-0.53^{\star *}$ & - & & \\
\hline 4. Task orientation & 0.62 & $2.16(0.55)$ & $0.53^{* *}$ & $-0.56^{\star *}$ & $0.40^{* *}$ & - & \\
\hline 5. Ego orientation & 0.49 & $3.37(0.75)$ & $-0.26^{\star *}$ & $0.27^{\star \star}$ & $-0.29^{\star *}$ & $-0.27^{\star *}$ & - \\
\hline
\end{tabular}

${ }^{*} p<0.05,{ }^{* *} p<0.001, \alpha=$ Cronbach's alpha. 
orientation $(\mathrm{r}=-0.26)$ and a positive significant relationship between argumentativeness with democratic style $(r=0.60)$ and task orientation $(r=0.53)$. At the same time, "Table 2" presents the Cronbach's alpha, mean scores and standard deviations of the variables.

Moreover, a series of simple regression analyses were conducted to examine the extent to which teaching leadership style and students' goal orientations could be predicted from the ratings of instructor's argumentativeness. The results indicated that perceived argumentativeness could predict significant variance in leadership style $\left(\mathrm{F}_{(2,251)}=84.43, \mathrm{p}<0.001\right)$ with an $\mathrm{R}_{2}$ of $40.2 \%$. Perceived argumentativeness explained $21.5 \%$ of the variance in democratic style ( $\beta$ $\left.=0.48, \mathrm{t}_{(254)}=-8.30, \mathrm{p}<0.001\right)$ and $6.5 \%$ of the variance in autocratic style $(\beta=$ $\left.-0.22, \mathrm{t}_{(254)}=-4.16, \mathrm{p}<0.001\right)$. Another linear regression analysis was conducted to predict students' goal orientations based on instructor argumentativeness. The results indicated that perceived instructor argumentativeness could predict significant variance in goal orientations $\left(\mathrm{F}_{(2,240)}=50.73, \mathrm{p}<0.001\right)$ with an $\mathrm{R}_{2}$ of $29.7 \%$. Argumentativeness explained $24.8 \%$ of the variance in task orientation $(\beta$ $\left.=0.67, \mathrm{t}_{(243)}=8.90, \mathrm{p}<0.001\right)$ and $2 \%$ of the variance in ego orientation $(\beta=$ $\left.-0.12, \mathrm{t}_{(243)}=-2.21, \mathrm{p}<0.05\right)$. The results of the regression analyses are presented in "Table 3".

In "Table 4", four types of relations between instructors' and students' options appear: 1) "learning by democracy and arguing", 2) "just democracy and arguing", 3) "just ego without learning" and 4) "learning by arguing”.

\section{Discussion}

Goal of this study is: a) to explore differences between genders and classes regarding argumentativeness, leadership style and goal orientations, b) to examine the relationship between perceived physical education instructors' argumentativeness and leadership style as perceived by students and students' goal orientations, c) to discuss the influence of instructor argumentativeness on their leadership style and student goal orientations and d) to suggest instructors' and students' typology. According to the results, statistically significant differences were observed in students' ego orientation between the genders and the classes of the students. Perceived instructors' argumentativeness was positively related to democratic teaching leadership style, students' task orientations and was negatively related to autocratic teaching leadership style, students' ego orientations.

Table 3. Regression analysis results according to argumentativeness.

\begin{tabular}{cccccc}
\hline & B & $95 \%$ CI B & SE & $\beta$ & $t$ \\
\hline Democratic style & 0.48 & $0.37,0.60$ & 0.06 & 0.48 & $8.30^{\star *}$ \\
Autocratic style & -0.24 & $-0.11,-0.32$ & 0.05 & -0.22 & $-4.16^{\star *}$ \\
Task orientation & 0.50 & $0.52,0.82$ & 0.08 & 0.67 & $8.90^{\star *}$ \\
Ego orientation & -0.12 & $-0.01,-0.22$ & 0.05 & -0.12 & $-2.21^{\star}$ \\
\hline
\end{tabular}

${ }^{* *} p<0.001,{ }^{*} p<0.05$. 
Table 4. Typology of leadership style, goal orientation and argumentativeness.

\begin{tabular}{|c|c|c|c|c|c|}
\hline & & $\begin{array}{c}\text { Learning by democracy } \\
\text { and arguing }\end{array}$ & $\begin{array}{l}\text { Just democracy } \\
\text { and arguing }\end{array}$ & $\begin{array}{l}\text { Just ego without } \\
\text { learning }\end{array}$ & $\begin{array}{l}\text { Learning by } \\
\text { arguing }\end{array}$ \\
\hline \multirow{6}{*}{ 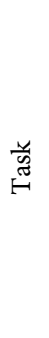 } & Learning a new exercise makes me exercise more & 0.056 & -0.282 & 0.158 & 0.565 \\
\hline & Doing the best I can & 0.011 & -0.231 & 0.132 & 0.462 \\
\hline & Working reallyhard & 0.803 & -0.025 & -0.057 & 0.036 \\
\hline & Learning something makes me want to exercise more & 0.813 & 0.005 & -0.086 & 0.167 \\
\hline & An exercise I'm learning is really right & 0.806 & 0.088 & -0.090 & 0.186 \\
\hline & Learning a new exercise trying hard & 0.075 & -0.306 & 0.139 & 0.445 \\
\hline \multirow{2}{*}{ 离 } & Going better than my friends & 0.037 & 0.088 & 0.760 & -0.187 \\
\hline & Others are doing bad, while I do not & 0.096 & -0.034 & 0.327 & 0.063 \\
\hline \multirow{5}{*}{ 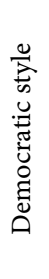 } & Treatsourmistakesgraciously & -0.130 & 0.511 & -0.149 & -0.100 \\
\hline & Lets children set their own goals & 0.893 & 0.053 & 0.007 & -0.081 \\
\hline & Lets us try things in our own way & 0.902 & 0.035 & 0.039 & -0.082 \\
\hline & Allows us to suggest ways of practicing & -0.060 & 0.653 & 0.038 & -0.133 \\
\hline & Takes into account the opinion of us & -0.043 & 0.557 & -0.100 & -0.198 \\
\hline \multirow{9}{*}{ 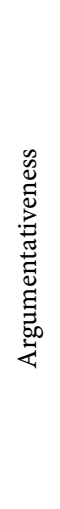 } & No talking with arguments when he has disagreements & -0.092 & 0.424 & 0.064 & 0.327 \\
\hline & Is enthusiastic when he attempts to resolve arguments & -0.091 & 0.543 & -0.095 & 0.078 \\
\hline & Enjoys a good discussion with arguments & 0.896 & 0.046 & 0.028 & -0.080 \\
\hline & Is glad to defend his point of view on a subject & 0.898 & 0.008 & 0.069 & -0.092 \\
\hline & Avoid talking about issues that disagree with us & 0.893 & 0.016 & 0.027 & -0.131 \\
\hline & Prefers to chat with us who rarely disagree with him & 0.890 & -0.003 & 0.065 & -0.156 \\
\hline & Thinks that a debate is an exciting challenge & 0.888 & 0.057 & 0.049 & -0.047 \\
\hline & Is not good at using arguments in a dispute with us & -0.098 & 0.536 & 0.022 & 0.332 \\
\hline & Tries to avoid discussing arguments when disagrees & -0.073 & 0.405 & 0.194 & 0.394 \\
\hline
\end{tabular}

Extraction Method: Principal Component Analysis. a 8 components extracted.

Also, perceived instructors' argumentativeness could significantly predict the variables of teaching leadership style and students' goal orientations. Four behavioral types are revealed: 1) "learning by democracy and arguing", 2) "just democracy and arguing", 3) "just ego without learning" and 4) "learning by arguing".

The findings of the present study seem to be consistent with the results of previous research, showing that instructors' argumentativeness is related with their behavioral characteristics in the classroom such as the relaxed and friendly attitude toward their students, as teachers themselves are considered to open to dialogue and different opinions, and to have the ability to listen carefully and comprehensively [39] [73]. However, the multilevel correlation conducted in this research is supposed to offer an overview of interactions. In addition, the argumentativeness was positively related to with the democratic leadership style and involves the active participation of students in decision-making and the re- 
spect and encouragement by the instructor to freely express ideas and to take initiatives [74] [75]. On the other hand, the negative correlation of argumentativeness with autocratic leadership style may be attributed to the fact that educators characterized by authoritarianism tend to give orders without taking into account the views of their students and not to justify their decisions [74] [76].

As [41] have argued, when instructors use arguments in the classroom, students are more satisfied with their communication and tend to develop positive emotions, both towards educators and towards the lesson. Additionally, instructors' argumentativeness is related with the achievement of students' personal goals, increased motivation for learning, facilitating the learning process, and improved interpersonal relations at class level, as the educator encourages students by arguing [27] [38] [77] [78] [79].

In this study, it was also found that teaching democratic style was positively correlated with their students' task orientation and negatively correlated with their ego orientation. These findings are in accordance with previous research indicating that the perceived teaching democratic style was positively correlated with students' task orientation in the physical education lesson while the autocratic leadership style was linked to the students' ego orientation [80] [81]. [74] found that adolescent athletes who regarded their coaches as supportive, are ready to offer guidance and positive feedback and less oriented towards achieving high performance or winning a race.

Many studies have also studied the effects of the perceived climate created by the educator on the motivation of children in sport [82] [83] [84] [85]. In particular, [86] found that students who thought their educators were supportive and that they had the ability to view and select activities during the physical education lessons were more entertained showed more interest in the lesson and they felt confident about their abilities. [82] found similar results indicating that pupils who had the ability to view and select activities during their physical education course believed that their instructors were promoting learning and participation, they enjoyed the lesson and continued to try, even if they did not succeed immediately.

As for the differences among argumentativeness, leadership style and personal orientations on the basis of gender and class, it was found that only the ego orientation depends on gender and class of students. It was found that the girls were more ego-oriented than the boys and that the students of the $5^{\text {th }}$ class were more ego-oriented compared to the children of the $6^{\text {th }}$ grade. The findings regarding the differences of ego orientation according to the class of students are in inconsistency with those of [87], who argued that the ego orientation is also increasing with the age. On the other hand, [88] found that the larger ones were more task-oriented than the smaller ones, and attributed this finding to maturity of older students and their long-term goals, according to which success is intertwined with the effort. Also, [89] found that the older ones enjoyed sport more than the younger ones. Finally, concerning the differences of the ego orientation in relation to the gender of the students, the findings of this research 
contradict the previous research. In particular, [87], through the study of children aged $10-17$ who participated in the physical education lesson, found that boys were more ego-oriented than girls. The same conclusion was reached by other researchers who dealt with children's personal orientations either in physical education or in the sport they practice individually [88] [90]. The differentiation of the findings of this research could be attributed to the fact that previous surveys included children from different levels of education at the same time and possibly the developmental changes that take place play a role in changing children's orientations.

The results of the present study are compatible with these of previous research suggesting that instructors' argumentativeness helped students express themselves freely improving their self-confidence and learning [9] [43] [44] [61] [91] [92]. Further research supported that instructors' personality plays a determinant role in the relationship with their students and influences their behavior, emotions, tactics and attitudes [78] [79] [93]. This study, particularly, revealed that instructor's perceived argumentativeness emerged as the most important predictor of teaching leadership style and of students' goal orientations, which is in accordance with previous findings showing that instructors' argumentativeness is positively related to their interpersonal attraction and responsibility, as well as to intrinsic reasons for discipline [36] [44].

Moreover, four types of relations between instructors' and students' options appear: 1) "learning by democracy and arguing", 2) "just democracy and arguing", 3) "just ego without learning", 4) "learning by arguing". The type 1 reflects a pattern of cooperation which could be regarded as quite "constructive" and "modern". The main goal of student is to learn (not to emphasize their ego). This seems to be achieved through a democratic and argumentative style in the part of instructors. It seems to be a quite sociable and learn-effective cooperation pattern. The type 2 is a unilateral tactic of the instructors. It depicts a class climate where the instructors are loyal to democratic and argumentative style, disregarding however the reaction of the students. The type 3 is a similar pattern in the part of students. Particularly, it depicts a class climate where the students' "ego" mentality dominates, independently of the instructors' style. Finally, the type 4 appears as sub-model of the type 1. Namely, learning is achieved by argumentation, independently of any democratic style. Such typologies have also been suggested in previous papers [94]-[107] but not so extensively focusing on the particular parameters and with the particular quantitative method.

Concisely, this study not only contributes to our understanding of factors associated with instructors' argumentativeness but also corroborates the results produced in previous studies. Enlarging the sample to various regions, age classes and social milieus constitutes a challenge for future research. The insightful analysis of more determinants is also an open question.

\section{Conflicts of Interest}

There are no known conflicts of interest associated with this publication. 


\section{References}

[1] Bekiari, A. (2016) Insights into Instructors' Verbal Aggressiveness and Students' Machiavellianism through Leadership Style and Motivational Climate. European Scientific Journal, 12, 90-110. https://doi.org/10.19044/esj.2016.v12n25p90

[2] Bekiari, A. (2012) Perceptions of Instructors' Verbal Aggressiveness and Physical Education Students' Affective Learning. Perceptual and Motor Skills, 115, 325-335. https://doi.org/10.2466/06.11.16.PMS.115.4.325-335

[3] Bekiari, A. and Hasanagas, N. (2016) Sociological Insights in the Education System: "Unlocking" the Power Relations. AfoiKyriakidi Editions S.A, Thessaloniki.

[4] Bekiari, A. and Hasanagas, N. (2016) "Educating” in Physical Education. Theoretical Approaches and Practical Inquiries. AfoiKyriakidi Editions S.A, Thessaloniki.

[5] Bekiari, A., Kokaridas, D. and Sakellariou, K. (2005) Verbal Aggressiveness of Physical Education Teachers and Students' Self-Reports of Behaviour. Psychological Reports, 96, 493-498. https://doi.org/10.2466/pr0.96.2.493-498

[6] Bekiari, A., Kokaridas, D. and Sakellariou, K. (2006) Associations of Students' Self-Reports of Their Teacher's Verbal Aggression, Intrinsic Motivation, and Perceptions of Reasons for Discipline in Greek Physical Education Classes. Psychological Reports, 98, 451-461. https://doi.org/10.2466/pr0.98.2.451-461

[7] Bekiari, A., Perkos, S. and Gerodimos, V. (2015) Verbal Aggression in Basketball: Perceived Coach Use and Athlete Intrinsic and Extrinsic Motivation. Journal of Physical Education and Sport, 15, 96-102.

[8] Bekiari, A. and Sakellariou, K. (2003) Perceived Instructor Verbal Aggressiveness and Student State Learning in Physical Education. Italian Journal of Sport Sciences, $1,251-256$.

[9] Bekiari, A. and Syrmpas, I. (2015) Coaches' Verbal Aggressiveness and Motivational Climate as Predictors of Athletes' Satisfaction. British Journal of Education, Society \& Behavioural Science, 9, 318-329. https://doi.org/10.9734/BJESBS/2015/17757

[10] Bekiari, A. and Tsiana, I. (2016) Exploring Instructors' Verbal Aggressiveness and Students' Personal Orientations and Reasons of Discipline in Physical Education Class. Advances in Physical Education, 6, 158-168. https://doi.org/10.4236/ape.2016.63018

[11] Bekiari, A., Koustelios, A. and Sakellariou, K. (2000) Instructors' Verbal Aggressiveness from Universities in Greece. Studi e Ricerche, 5, 225-232.

[12] Bekiari, A. and Petanidis, D. (2016) Exploring Teachers' Verbal Aggressiveness through Interpersonal Attraction and Students' Intrinsic Motivation. Open Journal of Social Sciences, 4, 72-85. https://doi.org/10.4236/jss.2016.412007

[13] Bekiari, A. and Tsaggopoulou, Th. (2016) Verbal Aggressiveness and Affective Learning in Physical Education. Advances in Physical Education, 6, 406-418. https://doi.org/10.4236/ape.2016.64041

[14] Bekiari, A., Digelidis, N. and Sakellariou, K. (2006) Perceived Verbal Aggressiveness of Coaches in Volleyball and Basketball: A Preliminary Study. Psychological Reports, 103, 526-530.

[15] Bekiari, A. and Digelidis, N. (2015) Measuring Verbal Aggressiveness in Sport and Education. International Journal of Physical Education, 52, 12-21.

[16] Bekiari, A. and Manoli, P. (2016) EFL Teacher Verbal Aggressiveness and Argumentativeness and Student Socio-Affective Strategy Use and Affective Learning: Exploring Possible Associations. Journal of Teacher Education and Educators, 5, 154-171.

[17] Bekiari, A., Patsiaouras, A., Kokaridas, D. and Sakellariou, K. (2006) Verbal Aggres- 
siveness and State Anxiety of Volleyball Players and Coaches. Psychological Reports, 99, 630-634.

[18] Hassandra, M., Bekiari, A. and Sakellariou, K. (2007) Physical Education Teacher's Verbal Aggression and Student's Fair Play Behaviors. The Physical Educator, 64, 94-101.

[19] Manoli, P. and Bekiari, A. (2015) EFL Teachers' Verbal Aggressiveness and Students' Intrinsic Motivation and Social-Affective Strategy Use: Investigating Possible Relations. Advances in Research, 5, 1-13. https://doi.org/10.9734/AIR/2015/19692

[20] Evagorou, M., Pilar Jimenez-Aleixandre, M. and Osborne, J. (2012) Should We Kill the Grey Squirrels? A Study Exploring Students' Justifications and Decision-Making. International Journal of Science Education, 34, 40-428. https://doi.org/10.1080/09500693.2011.619211

[21] Osborne, J. (2010) An Argument for Arguments in Science Classes. Phi Delta Kappan, 91, 62-65. https://doi.org/10.1177/003172171009100413

[22] Smith, N.S. (2009) Toward an Understanding of Moderate Argumentativeness: Assessing and Identifying the Impact of Trait and Situational Factors. PhD Thesis, University of Akron, Akron.

[23] Infante, D.A. and Rancer, A.S. (1982) A Conceptualization and Measure of Argumentativeness. Journal of Personality Assessment, 46, 72-80. https://doi.org/10.1207/s15327752jpa4601_13

[24] Rancer, A.S. and Avtgis, T.A. (2014) Argumentative and Aggressive Communication: Theory, Research, and Application. 2nd Edition, Peter Lang, New York.

[25] Rancer, A.S. and Avtgis, T.A. (2006) Argumentative and Aggressive Communication: Theory, Research, and Application. Sage, Thousand Oaks, CA.

[26] Martin, M.M. and Anderson, C.M. (1996) Argumentativeness and Verbal Aggressiveness. Journal of Social Behavior and Personality, 11, 547-554.

[27] Myers, S. (1998) Sibling Communication Satisfaction as a Function of Interpersonal Solidarity, Individualized Trust, and Self-Disclosure. Communication Research Reports, 15, 309-317. https://doi.org/10.1080/08824099809362127

[28] Myers, S., Edwards, C., Wahl, S. and Martin, M. (2007) The Relationship between Perceived Instructor Aggressive Communication and College Student Involvement. Communication Education, 56, 495-508. https://doi.org/10.1080/03634520701466398

[29] Schullery, N.M. and Schullery, S.E. (2003) Relationship of Argumentativeness to Age and Higher Education. Western Journal of Communication, 67, 207-223. https://doi.org/10.1080/10570310309374767

[30] DeWine, S., Nicotera, A. and Parry, D. (1991) Argumentativeness and Aggressiveness the Flip Side of Gentle Persuasion. Management Communication Quarterly, 4, 386-411. https://doi.org/10.1177/0893318991004003008

[31] Infante, D. and Gorden, W. (1989) Argumentativeness and Affirming Communicator Style as Predictors of Satisfaction/Dissatisfaction with Subordinates. Communication Quarterly, 37, 81-90. https://doi.org/10.1080/01463378909385529

[32] Infante, D., Anderson, C., Martin, M., Herington, A. and Kim, J. (1993) Subordinates' Satisfaction and Perceptions of Superiors' Compliance-Gaining Tactics, Argumentativeness, Verbal Aggressiveness, and Style. Management Communication Quarterly, 6, 307-326. https://doi.org/10.1177/0893318993006003004

[33] Lin, Y., Rancer, A. and Kong, Q. (2007) Family Communication Patterns and Argumentativeness: An Investigation of Chinese College Students. Human Communication, 10, 121-135. 
[34] Snyder, M. (1993) Argument versus Dialogue: A Response to Luepnitz, Madigan and Other Argumentative Authors. Journal of Family Therapy, 15, 81-86. https://doi.org/10.1111/j.1467-6427.1993.00744.X

[35] Rancer, A., Avtgis, T., Kosberg, R. and Whitecap, V. (2000) A Longitudinal Assessment of Trait Argumentativeness and Verbal Aggressiveness between Seventh and Eighth Grades. Communication Education, 49, 114-119. https://doi.org/10.1080/03634520009379197

[36] Bekiari, A. and Pylarinou, M. (2017) Instructor Argumentativeness and SocioCommunicative Style and Student Discipline: Using Physical Education Students' Class as an Illustration. Open Journal of Social Sciences, 5, 122-136. https://doi.org/10.4236/jss.2017.53011

[37] Edwards, C. and Myers, S.A. (2007). Perceived Instructor Credibility as a Function of Instructor Aggressive Communication. Communication Research Reports, 24, 47-53. https://doi.org/10.1080/08824090601128141

[38] Myers, S.A. (2002) Perceived Aggressive Instructor Communication and Student State Motivation, Learning, and Satisfaction. Communication Reports, 15, 113-121. https://doi.org/10.1080/08934210209367758

[39] Myers, S. and Rocca, K. (2000)The Relationship between Perceived Instructor Communicator Style, Argumentativeness, and Verbal Aggressiveness. Communication Research Reports, 17, 1-12. https://doi.org/10.1080/08824090009388745

[40] Myers, S.A. and Rocca, K.A. (2001) Perceived Instructor Argumentativeness and Verbal Aggressiveness in the College Classroom: Effects on Student Perceptions of Climate, Apprehension, and State Motivation. Western Journal of Communication, 65, 113-137. https://doi.org/10.1080/10570310109374696

[41] Myers, S. and Knox, R. (2000) Perceived Instructor Argumentativeness and Verbal Aggressiveness and Student Outcomes. Communication Research Reports, 17, 299 309. https://doi.org/10.1080/08824090009388777

[42] Schrodt, P. (2003) Students' Appraisals of Instructors as a Function of Students' Perceptions of Instructors' Aggressive Communication. Communication Education, 52, 106-121. https://doi.org/10.1080/03634520302468

[43] Hamilton, M. and Hample, D. (2011) Testing Hierarchical Models of Argumentativeness and Verbal Aggressiveness. Communication Methods and Measures, 5, 250-273. https://doi.org/10.1080/19312458.2011.596991

[44] Syrmpas, I. and Bekiari, A. (2015) The Relationship between Perceived Physical Education Teacher's Verbal Aggressiveness and Argumentativeness with Students' Interpersonal Attraction. Inquiries in Sport \& Physical Education, 13, 21-32.

[45] Mercier, H. and Sperber, D. (2011) Why Do Humans Reason? Arguments for an Argumentative Theory. Behavioral and Brain Sciences, 34, 57-74. https://doi.org/10.1017/S0140525X10000968

[46] Yáñez, C.S. (2012) Mercier and Sperber's Argumentative Theory of Reasoning: From Psychology of Reasoning to Argumentation Studies. Informal Logic, 32, 132 159. https://doi.org/10.22329/il.v32i1.3536

[47] Song, Y., Deane, P., Graf, E.A. and van Rijn, P. (2013) Using Argumentation Learning Progressions to Support Teaching and Assessments of English Language Arts. $R \& D$ Connections, 22, 1-14.

[48] Guerrero, L.K. and Gross, M.A. (2014) Argumentativeness, Avoidance, Verbal Aggressiveness, and Verbal Benevolence as Predictors of Partner Perceptions of an Individual's Conflict Style. Negotiation and Conflict Management Research, 7, 99-120. $\underline{\text { https://doi.org/10.1111/ncmr.12029 }}$ 
[49] Chelladurai, P. and Saleh, S.D. (1980) Dimensions of Leader Behavior in Sports: Development of a Leadership Scale. Journal of Sport Psychology, 2, 34-45. https://doi.org/10.1123/jsp.2.1.34

[50] Bray, S.R., Millen, J.A., Eidsness, J. and Leuzinger, C. (2005) The Effects of Leadership Style and Exercise Program Choreography on Enjoyment and Intentions to Exercise. Psychology of Sport and Exercise, 6, 415-425.

[51] Foels, R., Driskell, J.E., Mullen, B. and Salas, E. (2000) The Effects of Democratic Leadership on Group Member Satisfaction: Integration. Small Group Research, 31, 676-701. https://doi.org/10.1177/104649640003100603

[52] Lewin, K. (1953) Studies in Group Decision. In: Cartwright, D. and Zander, A., Eds., Group Dynamics: Research and Theory, Harper \& Row, New York, 287-301.

[53] Chatzisarantis, N.L. and Hagger, M.S. (2009) Effects of an Intervention Based on Self-Determination Theory on Self-Reported Leisure-Time Physical Activity Participation. Psychology and Health, 24, 29-48. https://doi.org/10.1080/08870440701809533

[54] Murray, N.P. (2006) The Differential Effect of Team Cohesion and Leadership Behavior in High School Sports. Individual Differences Research, 4, 216-225.

[55] Surujlal, J. and Dhurup, M. (2012) Athlete Preference of Coach's Leadership Style: Sport Management. African Journal for Physical Health Education, Recreation and Dance, 18, 111-121.

[56] Moen, F., Hoigaard, R. and Peters, D. (2014) Performance Progress and Leadership Behavior. International Journal of Coaching Science, 8, 67-79.

[57] Hampson, R. and Jowett, S. (2014) Effects of Coach Leadership and Coach-Athlete Relationship on Collective Efficacy. Scandinavian Journal of Medicine \& Science in Sports, 24, 454-460. https://doi.org/10.1111/j.1600-0838.2012.01527.x

[58] Lloyd, K. and Little, D. (2010) Self-Determination Theory as a Framework for Understanding Women's Psychological Well-Being Outcomes from Leisure-Time Physical Activity. Leisure Sciences, 32, 369-385. https://doi.org/10.1080/01490400.2010.488603

[59] Fransen, K., Vanbeselaere, N., De Cuyper, B., Broek, G. and Boen, F. (2014) The Myth of the Team Captain as Principal Leader: Extending the Athlete Leadership Classification within Sport Teams. Journal of Sports Sciences, 32, 1389-1397. https://doi.org/10.1080/02640414.2014.891291

[60] Monemi, S.T. and Moghaddam, A. (2013) The Relationship between Leadership Style and Competitive Anxiety of Female Athletes. International Journal of Sport Studies, 3, 1387-1392.

[61] Bekiari, A. (2014) Verbal Aggressiveness and Leadership Style of Sports Instructors and Their Relationship with Athletes' Intrinsic Motivation. Creative Education, 5, 114-121. https://doi.org/10.4236/ce.2014.52018

[62] Nicholls, J. (1984) Achievement Motivation: Conceptions of Ability, Subjective Experience, Task Choice, and Performance. Psychological Review, 91, 328-346. https://doi.org/10.1037/0033-295X.91.3.328

[63] Nicholls, J. (1989) The Competitive Ethos and Democratic Education. Harvard University Press, Cambridge, MA.

[64] Duda, J.L. (1989) Relationship between Task and Ego Orientation and the Perceived Purpose of Sport among High School Athletes. Journal of Sport and Exercise Psychology, 11, 318-335. https://doi.org/10.1123/jsep.11.3.318

[65] Kokaridas, D., Bekiari, A. and Sakellariou, K. (2005) Students' Goal Orientations, Perceived Motivation Climate and Their Relation with the Selection of the Specialty. 
Journal of Human Movement Studies, 48, 181-194.

[66] Theodorakis, I., Goudas, M. and Papaioannou, A. (1998) Aggression and Violence in Sport. In: Theodorakis, I., Goudas, M. and Papaioannou, A., Eds., The Psychology of Supremacy in Sport, Christodoulidis Publications, Thessaloniki, 274-289.

[67] Linnenbrink, E.A. and Pintrich, P.R. (2000) Multiple Pathways to Learning and Achievement: The Role of Goal Orientation in Fostering Adaptive Motivation, Affect, and Cognition. In: Sansone, C. and Harackiewicz, J.M., Eds., Intrinsic and EXtrinsic Motivation: The Search for Optimal Motivation and Performance, Academic Press, San Diego, 195-227.

[68] Linnenbrink, E.A. and Pintrich, P.R. (2002) Achievement Goal Theory and Affect: An Asymmetrical Bidirectional Model. Educational Psychologist, 37, 69-78. https://doi.org/10.1207/S15326985EP3702_2

[69] Theodosiou, A. and Papaioannou, A. (2006) Motivational Climate, Achievement Goals and Metacognitive Activity in Physical Education and Exercise Involvement in Out-of-School Setting. Psychology of Sport and Exercise, 7, 361-379.

[70] Vassiou, A. (2014) Motivations, Feelings and Performance of Secondary School Students: Interactions with the Teachers' Motivations and Feelings at School Level. PhD Thesis, University of Thessaly, Lamia, Greece.

[71] Papaioannou, A. and Macdonald, A.I. (1993) Goal Perspectives and Purposes of Physical Education as Perceived by Greek Adolescents. Physical Education Review, 16, 41-48.

[72] Papaioannou, A. and Theodorakis, Y. (1996) A Test of Three Models for the Prediction of Intention for Participation in Physical Education Lessons. International Journal of Sport Psychology, 27, 383-399.

[73] Driver, R., Newton, P. and Osborne, J. (2000) Establishing the Norms of Scientific Argumentation in Classrooms. Science Education, 84, 287-312. https://doi.org/10.1002/(SICI)1098-237X(200005)84:3<287::AID-SCE1>3.0.CO;2-A

[74] Barić, R. and Bucik, V. (2009) Motivational Differences in Athletes Trained by Coaches of Different Motivational and Leadership Profiles. Kineziologija, 41, 181194.

[75] Somech, A. (2005) Directive versus Participative Leadership: Two Complementary Approaches to Managing School Effectiveness. Educational Administration Quarterly, 41, 777-800. https://doi.org/10.1177/0013161X05279448

[76] Belias, D. and Koustelios, A. (2014) Organizational Culture and Job Satisfaction: A Review. International Review of Management and Marketing, 4, 132-149.

[77] Infante, D.A. (1981) Trait Argumentativeness as a Predictor of Communicative Behavior in Situations Requiring Argument. Communication Studies, 32, 265-272.

[78] Infante, D.A. and Rancer, A.S. (1996) Argumentativeness and Verbal Aggressiveness: A Review of Recent Theory and Research. Annals of the International Communication Association, 19, 319-352. https://doi.org/10.1080/23808985.1996.11678934

[79] Rancer, A.S. and Infante, D.A. (1985) Relations between Motivation to Argue and Argumentativeness of Adversaries. Communication Quarterly, 33, 209-218. https://doi.org/10.1080/01463378509369599

[80] Bennett, T. and Nelson, M. (2015) The Effect of Coaching Styles and Athletes' Goal: Orientation on Level of Enjoyment in Sport. Journal of the Oklahoma Association for Health, Physical Education, Recreation, and Dance, 52.

[81] Kokkonen, J.A., Kokkonen, M.T., Telama, R.K. and Liukkonen, J.O. (2013) Teachers' Behavior and Pupils' Achievement Motivation as Determinants of Intended 
Helping Behavior in Physical Education. Scandinavian Journal of Educational Research, 57, 199-216. https://doi.org/10.1080/00313831.2011.628692

[82] Ferrer-Caja, E. and Weiss, M.R. (2000) Predictors of Intrinsic Motivation among Adolescent Students in Physical Education. Research Quarterly for Exercise and Sport, 71, 267-279. https://doi.org/10.1080/02701367.2000.10608907

[83] Fry, M.D. and Newton, M. (2003) Application of Achievement Goal Theory in an Urban Youth Tennis Setting. Journal of Applied Sport Psychology, 15, 50-66. https://doi.org/10.1080/10413200305399

[84] Selfriz, J.J., Duda, J.L. and Chi, L. (1992) The Relationship of Perceived Motivational Climate to Intrinsic Motivation and Beliefs about Success in Basketball. Journal of Sport and Exercise Psychology, 14, 375-391. https://doi.org/10.1123/jsep.14.4.375

[85] Theeboom, M., De Knop, P. and Weiss, M.R. (1995) Motivational Climate, Psychological Responses, and Motor Skill Development in Children's Sport: A Field-Based Intervention Study. Journal of Sport and Exercise Psychology, 17, 294-311. https://doi.org/10.1123/jsep.17.3.294

[86] Goudas, M. and Biddle, S. (1994) Perceived Motivational Climate and Intrinsic Motivation in School Physical Education Classes. European Journal of Psychology of Education, 9, 241-250. https://doi.org/10.1007/BF03172783

[87] Digelidis, N. and Papaioannou, A. (1999) Age-Group Differences in Intrinsic Motivation, Goal Orientations and Perceptions of Athletic Competence, Physical Appearance and Motivational Climate in Greek Physical Education. Scandinavian Journal of Medicine \& Science in Sports, 9, 375-380. https://doi.org/10.1111/j.1600-0838.1999.tb00259.x

[88] Chin, N.S., Khoo, S. and Low, W.Y. (2012) Self-Determination and Goal Orientation in Track and Field. Journal of Human Kinetics, 33, 151-161. https://doi.org/10.2478/v10078-012-0054-0

[89] McCarthy, P.J., Jones, M.V. and Clark-Carter, D. (2008) Understanding Enjoyment in Youth Sport: A Developmental Perspective. Psychology of Sport and Exercise, 9, 142-156.

[90] Bakirtzoglou, P. and Ioannou, P. (2011) Goal Orientations, Motivational Climate and Dispositional Flow in Greek Secondary Education Students Participating in Physical Education Lesson: Differences Based on Gender. Facta Universitatis, Series. Physical Education and Sport, 9, 295-306.

[91] Bekiari, A. and Hasanagas, N. (2015) Verbal Aggressiveness Exploration through Complete Social Network Analysis: Using Physical Education Students' Class as an Illustration. International Journal of Social Science Studies, 3, 30-49. https://doi.org/10.11114/ijsss.v3i3.729

[92] Hasanagas, N. and Bekiari, A. (2015) Depicting Determinants and Effects of Intimacy and Verbal Aggressiveness Target through Social Network Analysis. Sociology Mind, 5, 162-175. https://doi.org/10.4236/sm.2015.53015

[93] Horn, T.S. (2002) Coaching Effectiveness in the Sport Domain. In: Horn, T.S., Ed., Advances in Sport Psychology, Human Kinetics, Champaign, IL, 309-354.

[94] Bekiari, A. (2017) Exploring Relations between Instructors' Verbal Aggressiveness and Argumentativeness and Students' Fair Play Behaviours and Machiavellianism. International Journal of Physical Education, 54, forthcoming.

[95] Bekiari, A., Deliligka, S. and Hasanagas, N. (2017) Analysing Networks of Verbal Aggressiveness and Motivation. Psychology, 8, 495-515. https://doi.org/10.4236/psych.2017.83031

[96] Bekiari, A., Deliligka, S. and Koustelios, A. (2016) Examining Relations of Aggres- 
sive Communication in Social Networks. Social Networking, 6, 38-52. https://doi.org/10.4236/sn.2017.61003

[97] Bekiari, A. and Hasanagas, N. (2016) Suggesting Indicators of Superficiality and Purity in Verbal Aggressiveness. An Application in Adult Education Class Networks of Prisoners. Open Journal of Social Sciences, 4, 279-292. https://doi.org/10.4236/jss.2016.43035

[98] Bekiari, A., Hasanagas, N., Theoharis, D., Kefalas, I. and Vasilou, A. (2015) The Role of Mathematical Object and the Educational Environment to Students' Interpersonal Relationships: An Application of Full Social Network Analysis. Proceedings of the 32 nd Congress Greek Mathematical Society (with International Participation), Kastoria, 799-812.

[99] Bekiari, A., Nikolaidou, Z. and Hasanagas, N. (2017) Typology of Motivation and Aggression on the Basis of Social Network Variables: Examples of Complementary and Nested Behavioral Types through Conventional Statistics. Social Networking, 6, 135-147. https://doi.org/10.4236/sn.2017.62008

[100] Bekiari, A., Pachi, V. and Hasanagas, N. (2017) Investigating Bullying Determinants and Typologies with Social Network Analysis. Journal of Computer and Communications, 5, 11-27. https://doi.org/10.4236/jcc.2017.57002

[101] Bekiari, A. and Spyropoulou, S. (2016) Exploration of Verbal Aggressiveness and Interpersonal Attraction through Social Network Analysis: Using University Physical Education Class as an Illustration. Open Journal of Social Sciences, 4, 145-155. https://doi.org/10.4236/jss.2016.46016

[102] Hasanagas, N. and Bekiari, A. (2017) An Exploration of the Relation between Hunting and Aggressiveness: Using Inmates Networks at Prison Secondary School as an Illustration. Social Networking, 6, 19-37. https://doi.org/10.4236/sn.2017.61002

[103] Theoharis, D. and Bekiari, A. (2016) The Influence of Mathematics and Learning Environment in Verbal Aggressiveness and Interpersonal Relations: A Dynamic Analysis of Social Networks. Proceedings of the 8 th International Congress Mathematical Society, Thessaloniki, 30 March-3 April 2016, 415-428.

[104] Theoharis, D. and Bekiari, A. (2016) Social Networks Analysis of Centrality: Case Study in Leadership Networks. Proceedings of the 33rd Congress Greek Mathematical Society (with International Participation), Chania, 4-6 November 2016, 250 260.

[105] Theoharis, D. and Bekiari, A. (2017) Applying Social Network Indicators in the Analysis of Verbal Aggressiveness at the School. Journal of Computer and Communications, 5, 169-181.

[106] Theoharis, D. and Bekiari, A. (2017) Cumulative Hierarchy Analysis (Katz Centrality) on Leadership Networks of Learning Communities. Proceedings of the 9 th International Congress Mathematical Society, Thessaloniki, 17-19 March 2017, 285297.

[107] Theoharis, D., Bekiari, A. and Koustelios, A. (2017) Exploration of Determinants of Verbal Aggressiveness and Leadership through Network Analysis and Conventional Statistics. Using School Class as an Illustration. Sociology Mind, 7, 27-43. https://doi.org/10.4236/sm.2017.72003 
Submit or recommend next manuscript to SCIRP and we will provide best service for you:

Accepting pre-submission inquiries through Email, Facebook, LinkedIn, Twitter, etc. A wide selection of journals (inclusive of 9 subjects, more than 200 journals)

Providing 24-hour high-quality service

User-friendly online submission system

Fair and swift peer-review system

Efficient typesetting and proofreading procedure

Display of the result of downloads and visits, as well as the number of cited articles Maximum dissemination of your research work

Submit your manuscript at: http://papersubmission.scirp.org/

Or contact jss@scirp.org 